\title{
THE ROLE OF BREAST-FEEDING IN THE PREVENTION OF ROTAVIRUS INFECTION
}

\author{
B. D. Schoub, O. W. Prozesky*, G. Lecatsas*, and Robyn Oosthuizen* \\ National Institute for Virology, Private Bag X4, Sandringham 2131, South Africa, and \\ * Department of Microbiology, University of Pretoria, Pretoria, South Africa
}

THE important role of breast-feeding in reducing the incidence and mortality of infantile gastroenteritis has been recognised since 1911 (Dudfield, 1912). Although a number of antibacterial factors have been recognised in human milk (Goldman and Smith, 1973) and specific antibodies against bacterial cellwall antigens (Allardyce et al., 1974; Goldblum et al., 1975) and enterotoxin (Holmgren et al., 1976; Stoliar et al., 1976) have been detected, similar protective factors against enteropathogenic viruses have not as yet been demonstrated. Specific antibodies against respiratory syncytial virus (Downham et al., 1976) and non-specific antiviral inhibitors (Falkler, Diwan and Halstead, 1975; Matthews et al., 1976) have been demonstrated in human colostrum and milk, but any effect on enteric viral pathogens has yet to be established.

Observations on rotavirus infection of calves (Woode, Jones and Bridger, 1975) and lambs (Snodgrass and Wells, 1976) and on transmissible gastroenteritis of swine (Abou-Youssef and Ristic, 1975) have revealed that immunity of the gastrointestinal tract to invasion by enteric pathogens is not related to serum antibodies but to the presence of secretory antibodies in the gut lumen. The latter antibodies may be either locally produced or ingested in colostrum or milk. Similarly, protection against human rotavirus infection is not associated with the presence of maternal serum antibody (Totterdell, Chrystie and Banatvala, 1976). In ewes and sows antibodies are produced in the milk by oral or intramammary immunisation but not by intramuscular immunisation (Bohl and Saif, 1975; Snodgrass and Wells, 1976).

In this paper we report the results of a two-part study of the possible immunity produced by colostrum and milk to rotavirus infection in human beings and mice. In the first part of the study the presence of antirotavirus antibodies in the colostrum and serum of mothers in the early post-partum stage was investigated; specimens were obtained from black mothers as the incidence of gastroenteritis is particularly high in their infants (Schoub et al., 1977b). In the second part of the study we used experimental rotavirus infection of mice to determine whether exposure of the dam to the agent during pregnancy would result in passive transfer of immunity to her offspring; the mouse was chosen in preference to the calf, lamb or pig because, as in man, the offspring receive maternal antibody via the placenta, as well as in the colostrum. In pigs and ruminants, transfer is exclusively colostral. In man, transfer occurs essentially through the placenta (Good and Papermaster, 1964).

Received 24 May 1977; accepted 11 July 1977.

J. MED. MICROBIOL.-VOL. 11 (1977) 


\section{MATERIALS AND METHODS}

Human samples. Colostrum and serum were obtained from 30 healthy mothers at the Baragwanath Maternity Hospital, Johannesburg, up to 2 days post partum. In addition, seven specimens of milk from mothers 2-6 months post partum were kindly provided by Dr. A. Zoutendyk of the Human Milk Bank, South African Institute for Medical Research. Colostrum and milk were de-fatted by centrifugation at $20000 \mathrm{~g}$ for $1 \mathrm{~h}$ in a Sorvall Super-speed RC2-B centrifuge, and clear whey was used for immunofluorescence and IgA determinations.

Animals. Balb/c mice (Charles River Inc., Massachusetts) kindly provided by $\mathrm{Mr}$ R. Ballard, University of Witwatersrand, and outbred Swiss laboratory mice were used in the experiments. These animals had been kept in separate houses some distance from the rotavirus laboratories. Before use, the mice were shown to be rotavirus-free by electronmicroscopy of stool suspensions.

Virus. Clarified suspensions of infected mouse gut in phosphate-buffered saline (PBS),

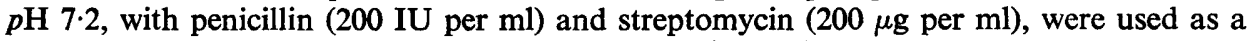
source of epizootic diarrhoea of infant mice virus (EDIM). The EDIM strain was kindly provided by Dr T. H. Flewett, Regional Virus Laboratory, Birmingham. The mouse infective doses (MID) were estimated by the technique of Much and Zajac (1972). One MID corresponded to a dilution of $10^{8}$ of the original clarified mouse-gut suspension.

Immunofluorescence. Serum, colostrum and milk specimens were absorbed overnight with vervet-monkey cells at $4^{\circ} \mathrm{C}$. Antirotavirus antibodies were assayed by immunofluorescence with antigen that consisted of vervet-monkey kidney cells infected with simian rotavirus (SA11) (Schoub, Lecatsas and Prozesky, 1977a). The teflon-coated slides containing SA11 antigen were incubated with the serum or whey specimens for $1 \mathrm{~h} \mathrm{at} 37^{\circ} \mathrm{C}$, before treatment with fluorescein-conjugated goat-antihuman immunoglobulin or antihuman IgA serum (Behring Diagnostics). A sample of hyperimmune-rabbit anti-SA11 serum with fluorescein-conjugated goat-antirabbit globulin (Behring Diagnostics) was used as a positive control, and an uninfected preparation of vervet-monkey kidney cells was substituted for the SA11-infected tissue to provide a negative control.

The mouse sera and milk curd preparations (see Mouse experiments) were absorbed overnight at $4^{\circ} \mathrm{C}$ with lyophilised uninfected-mouse intestine. Cryostat sections of mouse jejunum 5 days after infection with EDIM virus were used as antigen and the technique was that used for the human samples except that the fluorescein-conjugated reagent consisted of rabbit anti-mouse immunoglobulin (Behring Diagnostics). Uninfected mouse-jejunum preparations and hyperimmune-rabbit anti-EDIM serum were used as negative and positive control reagents respectively.

Measurement of IgA in human colostrum and milk. IgA levels were determined by radial immunodiffusion with commercially-available plates (Tri-Partigen, Behring Diagnostics).

Electronmicroscopy of mouse faeces. Faeces collected from the dams and sucklings were suspended in PBS and prepared for electronmicroscopy as described by Schoub et al. (1975).

Mouse experiments. Twenty-one outbred and $10 \mathrm{Balb} / \mathrm{c}$ pregnant dams were bled from the tip of the tail shortly before parturition. At 2 days of age, the sucklings were inoculated per os with approximately $0.1 \mathrm{ml}$ of an EDIM preparation containing 10 MID. Each litter contained from four to eight sucklings. Eight days after inoculation the sucklings were killed and the dams immediately mated again. Two days after birth of the second litter the dams were again bled from the tail and the sucklings were immediately inoculated per os with 10 MID of EDIM. The sucklings were observed for signs of diarrhoea and 5 days after inoculation were killed and bled by decapitation. The stomachs were carefully removed, washed with saline to remove all traces of blood, and cut open along the lesser curvature with small sharp-pointed scissors. The milk curds were gently removed with clean forceps, emulsified in 2 volumes of PBS, and treated as described above for the human colostrum and milk specimens. First and second generation litters of a further 12 dams (six Balb/c and six outbred) were treated as above, but both the first and the second litters were left alive for 3 weeks and the duration of illness was noted. 
Twelve adult dams (six Balb/c and six outbred) were inoculated intraperitoneally at times that corresponded with the oral inoculations of the first and second litters described above. The preparation used for inoculation was derived from the aqueous layer formed by centrifugation at $1500 \mathrm{~g}$ for $1 \mathrm{~h}$ of a saline suspension of EDIM-infected mouse gut homogenised with an equal volume of Freon $113(1,1,2$-trichlorotrifluoroethane). The mice were bled initially from the tail and then given two intraperitoneal inoculations of $0.1 \mathrm{ml}$ at 4week intervals. Five days after the second inoculation they were bled again.

\section{RESULTS}

Serology of human serum, colostrum and milk

Antirotavirus antibodies were detected in 29 of 30 sera and $13(43 \%)$ had titres of 160 or higher (table). However, only 4 of $30(13 \%)$ colostrum specimens were positive, and the titres were low (10); nevertheless, large amounts of IgA

\section{TABLE}

Antibody against rotavirus in human serum and colostrum

\begin{tabular}{|c|c|c|c|}
\hline \multirow{2}{*}{$\begin{array}{l}\text { Healthy } \\
\text { mother } \\
\text { number }\end{array}$} & \multicolumn{2}{|c|}{ Antirotavirus IFA titres in } & \multirow{2}{*}{$\begin{array}{l}\text { Colostral IgA } \\
(\mathrm{mg} \text { per } \mathrm{ml})\end{array}$} \\
\hline & serum & colostrum & \\
\hline 1 & 80 & $<10$ & 1320 \\
\hline 2 & 160 & $<10$ & 196 \\
\hline 3 & 80 & $<10$ & 68 \\
\hline 4 & 40 & $<10$ & 1820 \\
\hline 5 & 40 & $<10$ & 254 \\
\hline 6 & 160 & $<10$ & 414 \\
\hline 7 & 320 & $<10$ & 1200 \\
\hline 8 & 80 & 10 & 1320 \\
\hline 9 & 640 & $<10$ & 132 \\
\hline 10 & 160 & $<10$ & 254 \\
\hline 11 & 40 & $<10$ & 325 \\
\hline 12 & 40 & $<10$ & $12 \mathrm{C}$ \\
\hline 13 & 40 & 10 & 1680 \\
\hline 14 & $<10$ & $<10$ & 414 \\
\hline 15 & 10 & $<10$ & 132 \\
\hline 16 & 20 & 10 & 1960 \\
\hline 17 & 40 & $<10$ & 414 \\
\hline 18 & 20 & $<10$ & 254 \\
\hline 19 & 160 & $<10$ & 196 \\
\hline 20 & 40 & $<10$ & 2540 \\
\hline 21 & 320 & $<10$ & 325 \\
\hline 22 & 640 & $<10$ & 980 \\
\hline 23 & 20 & $<10$ & 414 \\
\hline 24 & 320 & $<10$ & 414 \\
\hline 25 & 20 & $<10$ & 196 \\
\hline 26 & 640 & $<10$ & 120 \\
\hline 27 & 1280 & $<10$ & 900 \\
\hline 28 & 20 & $<10$ & 680 \\
\hline 29 & 160 & $<10$ & 325 \\
\hline 30 & 160 & 10 & 980 \\
\hline
\end{tabular}

IFA $=$ Indirect fluorescent antibody. Fluorescein-conjugated goat-antihuman immunoglobulin and antihuman IgA were used respectively for serum and colostrum antirotavirus determinations. 
were present in the colostrum specimens (table). None of the milk specimens were positive and $\operatorname{IgA}$ levels varied from 20 to $200 \mathrm{mg}$ per $100 \mathrm{ml}$.

\section{Clinical course of the infection in mice}

All the sucklings developed severe diarrhoea about $72 \mathrm{~h}$ after inoculation but there were no deaths. No difference was observed between the first and second generation litters in respect of the severity of disease or the length of the incubation period, and no correlation could be found between the presence of antibodies in the colostrum or the titre in the serum, and the clinical picture. The first and second generation litters kept alive for 3 weeks did not differ in respect of the duration of the disease; the illness subsided after 14 days with no mortality.

None of the dams developed diarrhoea despite ingesting large amounts of heavily infected faeces during their attempts to clean their offspring. Electronmicroscopical examination showed that the faeces of the dams immediately after inoculation of the sucklings, as well as those of the sucklings themselves, were very heavily infected with rotavirus. However, after 10-14 days, the degree of viral shedding by the dams decreased strikingly although virus was detectable throughout the experiment.

\section{Serology of mouse serum and milk}

The pre-test serum samples of the dams of the inoculated litters, as well as those of the parenterally-inoculated dams, were all negative for antirotavirus antibody.

The test sera of the dams of the inoculated litters were all positive, with titres of 10-40. Similarly the test sera of the parenterally-inoculated dams were all positive, two of them with titres of 80 and the rest with titres of 10-40. However, sera from the sucklings as well as the mouse milk-curd preparations were all negative.

\section{Discussion}

Although the value of breast-feeding in the prevention of gastroenteritis has been established for over half a century, there is still considerable controversy as to whether breast milk has intrinsic immune properties. A number of antibacterial factors are more abundant in human milk than in bovine milk (Goldman and Smith, 1973) and specific antibacterial and anti-enterotoxic antibodies have been demonstrated in human milk (Goldblum et al., 1975; Holmgren et al., 1976; Stoliar et al., 1976). Furthermore, breast milk has been successfully used therapeutically in bacterial gastroenteritis (Svirsky-Gross, 1958). However, antiviral factors active against enteropathogenic viruses have not been found in human milk, although specific colostral antibodies have been demonstrated in ungulates such as pigs, calves and lambs (Abou-Youssef and Ristic, 1975; Woode et al., 1975; Snodgrass and Wells, 1976) in which the transfer of passive immunity to the newborn is exclusively via the colostrum (Good and Papermaster, 1964). 
The association of bottle-feeding with gastroenteritis is thought by some workers to result from poor hygiene and greater opportunity for the spread of infection, rather than from the lack of immune factors in artificial feeds. Our findings in a previous study of infantile gastroenteritis in black infants tend to support this view (Schoub et al., 1977b). We found that the isolation rate of pathogens from patients who have been on combined bottle- and breast-feeds was not significantly different from that of bottle-fed patients. However, the association of breast-feeding with protection from gastroenteritis was apparent from our observation that only one of 37 patients $(3 \%)$ was solely breast-fed, but that the comparable figure for age-matched non-diarrhoeic controls was $16 \%$. It thus appears that while breast-feeding is associated with a significantlylow attack rate of gastroenteritis, this " protective" effect disappears when artificial feeds are introduced into the diet in combination with breast-feeding.

The levels of antirotavirus antibodies in the human and murine colostrum and milk specimens were low or absent, despite adequate amounts of $\operatorname{IgA}$ and the presence of antibody in nearly all of the sera. The dams exposed to the virus through ingesting contaminated faeces displayed a serum humoral response equivalent to that of dams that were parenterally immunised. The lack of antibodies in the milk curd specimens accords with the finding, based on clinical observation, that there was no difference in susceptibility between the first and second generation litters of dams exposed to the antigen between litters. Similarly, despite the presence of serum antibodies in most of the human population (Schoub et al., unpublished) and in 29 of 30 subjects described above, antirotavirus antibodies were absent from most of the colostrum and milk specimens, and present at low titre in only a few.

The absence of resistance in offspring to enteric infection, despite the presence of specific antibodies in the maternal serum, has been demonstrated in calves (Woode et al., 1975), lambs (Snodgrass and Wells, 1976), swine (AbouYoussef and Ristic, 1975) and man (Totterdell et al., 1976). Antibody-secreting lymphocytes found in the colostrum are derived from sensitised gut lymphocytes that migrate from the gastrointestinal tract through the blood stream to the mammary gland where they cause a clonal proliferation of antibody-producing cells (Parmely, Beer and Billingham, 1976). Thus, colostral B cells produce type-specific IgA antibodies to Escherichia coli in the gastrointestinal tract (Parmely et al., 1976), and colostral $\mathrm{T}$ cells are transformed readily when exposed to gut-derived $E$. coli $\mathrm{K} 1$ antigen, but not to histocompatibility or foreign antigens (Pierce, 1976). The gut, together with other mucosal surfaces, possesses an immunological system for protection against enteric antigens that operates to a large extent independently of the systemic immune system (Pierce, 1976). During lactation, the mammary gland appears to be integrated into the gut immune system thus forming a gut-mammary axis. Protection of an infant against an enteric pathogen by colostrum will thus be dependent on previous infection of the mother by that pathogen or by an organism with similar antigenicity. Thus, mothers infected with $E$. coli $\mathrm{O} 83$ during the last month of pregnancy secreted specific IgA-producing lymphocytes in their colostrum (Parmely et al., 1976), and in sows infected with transmissible gastroenteritis 
virus good passive immunity was transferred to the litters when the sows developed diarrhoea (Bohl and Saif, 1975). In human beings, rotavirus gastroenteritis is a disease that is rare in older children and adults (Flewett, 1976), and mice more than 12 days of age are resistant to experimental infection (Kraft, 1957). In our experiments, dams exposed to large amounts of virus through ingestion of infected faeces showed an initial heavy shedding of virus that did not persist after 10 to 14 days. The resistance to infection shown by adult human beings and mice may be the cause of a failure to produce sensitised lymphocytes in the gut, and thus of an absence of specific immunoglobulinsecreting cells in the colostrum.

The above experimental evidence, together with our previous clinical observations (Schoub et al., 1977b), strongly suggest that specific-antirotavirus immune factors are not present in human breast milk. The observed association of bottle-feeding with gastroenteritis thus appears to be the result of increased opportunity for the spread of infection. We strongly support current efforts to encourage breast-feeding, especially in developing countries where hygiene is poor and gastroenteritis is responsible for a large proportion of infant mortality. In addition, there is considerable evidence of the benefits of breastfeeding with regard to non-infectious as well as infectious diseases (Jelliffe and Jelliffe, 1976). The introduction of bottle-feeding as an addition to breastfeeding imposes a risk of rotavirus gastroenteritis similar to that experienced by infants fed by bottle alone.

\section{SUMMARY}

Breast-fed infants are less susceptible to gastroenteritis than bottle-fed infants. Antibodies against rotavirus, the major pathogen of infantile gastroenteritis, were sought in human sera, colostrum and milk specimens by immunofluorescence. An experimental murine-rotavirus model was established by infecting the second litters of dams 4 weeks after infecting their first litters. Antibodies were absent from human and murine colostrum and milk specimens despite being present in virtually all sera, and the second mouse litters were as susceptible as the first. The inability of rotavirus to infect adult human beings and mice may prevent the formation of gut-derived antibody-secreting lymphocytes in milk, and thus prevent transmission of passive immunity. The association of bottle-feeding with rotavirus gastroenteritis appears to be the result of increased opportunity for spread of infection rather than of the absence of specific protective antibody.

The assistance of Mrs Major-Korth, Chief Matron, Baragwanath Hospital, and her nursing staff, as well as the excellent technical assistance of Miss G. McGillivray, is gratefully acknowledged. We would also like to thank Dr H. Beukes, Superintendent of Baragwanath Hospital, and Dr J. de Beer, Secretary for Health, for permission to publish.

\section{REFERENCES}

Abou-Youssef, M. H. AND Ristic, M. 1975. Protective effect of immunoglobulins in serum and milk of sows exposed to transmissible gastroenteritis virus. Can. J. comp. Med., $39,41$. 
Allardyce, R. A., Shearman, D. J. C., McClelland, D. B. C., Marwick, K., Simpson, A. J. AND LAIDLAW, R. B. 1974. Appearance of specific colostrum antibodies after clinical infection with Salmonella typhimurium. Br. med. J., 3, 307.

BoHL, E. H. AND SAIF, L. J. 1975. Passive immunity in transmissible gastroenteritis of swine: immunoglobulin characteristics of antibodies in milk after inoculating virus by different routes. Infect. Immun., 11, 23.

Downham, M. A. P. S., Scott, R., Sims, D. G., Webb, J. K. G. and Gardner, P. S. 1976. Breast-feeding protects against respiratory syncytial virus infections. Br. med.J., 2, 274.

Dudfield, R. 1912. Diarrhoea in 1911. Proc. R. Soc. Med., Epidemiological Section, $5,99$.

Falkler, W. A., Diwan, A. R. and Halstead, S. B. 1975. A lipid inhibitor of dengue virus in human colostrum and milk: with a note on the absence of anti-dengue secretory antibody. Archs Virol., 46, 3.

Flewett, T. H. 1976. Diagnosis of enteritis virus. Proc. R. Soc. Med., 69, 693.

Goldblum, R. M., Ahlstedt, S., Carlsson, B., Hanson, L. A., Jodal, U., Lidin-Janson, G. AND SoHL-AKerLund, A. 1975. Antibody-forming cells in human colostrum after oral immunisation. Nature, Lond., 257, 797.

Goldman, M. S. ANd Smith, C. W. 1973. Host resistance factors in human milk. J.Pediat., 82, 1082.

Good, R. A. and Papermaster, B. W. 1964. Ontogeny and phylogeny of adaptive immunity. Adv. Immunol., 4, 1.

Holmgren, J., Hanson, A., Carlson, B., Lindbad, B. S. and Rahimtoola, J. 1976. Neutralizing antibodies against Escherichia coli and Vibrio cholerae enterotoxins in human milk from a developing country. Scand. J. Immunol., 5, 867.

Jelliffe, D. B. AND Jelliffe, E. F. P. 1976. Breast is best. Lancet, 2, 635.

KRAFT, L. M. 1957. Studies on the etiology and transmission of epidemic diarrhea of infant mice. J. exp. Med., 106, 743.

Matthews, T. H. J., Nair, C. D. G., Lawrence, M. K. and Tyrrell, D. A. J. 1976. Antiviral activity in milk of possible clinical importance. Lancet, 2, 1387.

Much, D. H. AND ZajaC, I. 1972. Purification and characterization of epizootic diarrhea of infant mice virus. Infect. Immun., 6, 1019.

Parmely, M. J., Beer, A. E. ANd Billingham, R. E. 1976. In vitro studies in the T-lymphocyte population of human milk. J. exp. Med., 144, 358.

PIERCE, N. F. 1976. Intestinal immunization with soluble bacterial antigens: the example of cholera toxoid. In Acute diarrhoea in childhood. Ciba Foundation Symposium No. 42 (New Series), edited by K. Elliot and J. Knight, Amsterdam, p. 129.

Schoub, B. D, Koornhof, H. J., Lecatsas, G., Prozesky, O. W., Freiman, I., Hartman, E. AND KASSEL, H. 1975. Viruses in acute summer gastroenteritis in black infants. Lancet, $1,1093$.

Schoub, B. D., Lecatsas, G. ANd Prozesky, O. W. 1977a. Antigenic relationship between human and simian rotaviruses. J. med. Microbiol., 10, 1.

Schoub, B. D., Greeff, A. S., Lecatsas, G., Prozesky, O. W., Hay, I. T., Prinsloo, J. G. AND BALlARD, R. C. 1977b. A microbiological investigation of acute summer gastroenteritis in black South African infants. J. Hyg., Camb., 78, 377.

Snodgrass, D. R. and Wells, P. W. 1976. Rotavirus infection in lambs: studies on passive protection. Archs Virol., 52, 201.

Stoliar, O. A., Pelley, R. P., Kaniecki-Green, E., Klaus, M. H. and Carpenter, C. C. J. 1976. Secretory IgA against enterotoxins in breast-milk. Lancet, 1, 1258.

SVIrsky-Gross, S. 1958. Pathogenic strains of Coli $(O, 111)$ among prematures and the use of human milk in controlling the outbreak of diarrhea. Annls paediat., 190, 109.

Totterdell, B. M., Chrystie, I. L. and Banatvala, J. E. 1976. Rotavirus infections in a maternity unit. Archs Dis. Childh., 51, 924.

WoOde, G. N., Jones, J. AND BRIDGER, J. C. 1975. Levels of colostral antibodies against neonatal calf diarrhoea virus. Vet. Res., 97, 148. 